\title{
Correction to: On-drug and drug-free remission by baseline symptom duration: abatacept with methotrexate in patients with early rheumatoid arthritis
}

\author{
Vivian P. Bykerk ${ }^{1}\left[\right.$. Gerd R. Burmester ${ }^{2} \cdot$ Bernard G. Combe $^{3} \cdot$ Daniel E. Furst $^{4} \cdot$ Tom W. J. Huizinga $^{5}$. \\ Harris A. Ahmad ${ }^{6}$. Paul Emery 7,8
}

Published online: 5 February 2019

(c) The Author(s) 2018

\section{Correction to: \\ Rheumatology International (2018) 38:2225-2231 \\ https://doi.org/10.1007/s00296-018-4173-3}

The article "On-drug and drug-free remission by baseline symptom duration: abatacept with methotrexate in patients with early rheumatoid arthritis", written by Vivian P.Bykerk, was originally published Online First without open access. After publication in volume [38], issue [12], page [2225-2231] the author decided to opt for Open Choice and to make the article an open access publication. Therefore, the copyright of the article has been changed to (c) The Author(s) 2018 and the article is forthwith distributed under the terms of the Creative Commons Attribution 4.0
International License (http://creativecommons.org/licenses/ by/4.0/), which permits use, duplication, adaptation, distribution and reproduction in any medium or format, as long as you give appropriate credit to the original author(s) and the source, provide a link to the Creative Commons license and indicate if changes were made.

The original article has been corrected.

Open Access This article is distributed under the terms of the Creative Commons Attribution 4.0 International License (http://creativeco mmons.org/licenses/by/4.0/), which permits unrestricted use, distribution, and reproduction in any medium, provided you give appropriate credit to the original author(s) and the source, provide a link to the Creative Commons license, and indicate if changes were made.

The original article can be found online at https://doi.org/10.1007/ s00296-018-4173-3.

Vivian P. Bykerk

bykerkv@hss.edu

1 Department of Rheumatology, Hospital for Special Surgery, Weill Cornell Medical College, 535 East 70th St, New York, NY 10021, USA

2 Department of Rheumatology and Clinical Immunology, Charité-University Medicine Berlin, Berlin, Germany

3 Department of Rheumatology, Service d'Immuno-Rheumatologie, Montpellier, France

4 Department of Medicine, University of California Los Angeles, Los Angeles, CA, USA

5 Department of Rheumatology, Leiden University Medical Center, Leiden, Netherlands

6 Headquarters Medical Immunology, Bristol-Myers Squibb, Princeton, NJ, USA

7 Leeds Institute of Rheumatic and Musculoskeletal Medicine, University of Leeds, Leeds, UK

8 NIHR Leeds Musculoskeletal Biomedical Research Unit, Leeds Teaching Hospitals NHS Trust, Leeds, UK 